\title{
Animal hoarding disorder: a systematic review
}

\author{
Luis Henrique Paloski \\ Elisa Arrienti Ferreira \\ Pontifícia Universidade Católica do Rio Grande do Sul, RS, Brasil \\ Dalton Breno Costa \\ Universidade Federal de Ciências da Saúde de Porto Alegre, RS, Brasil \\ María Laura del Huerto \\ Pontifícia Universidade Católica do Rio Grande do Sul, RS, Brasil \\ Camila Rosa de Oliveira \\ Faculdade Meridional, RS, Brasil \\ Irani Iracema de Lima Argimon \\ Tatiana Quarti Irigaray \\ Pontifícia Universidade Católica do Rio Grande do Sul, RS, Brasil
}

\begin{abstract}
The main objective of this systematic review was to identify studies that investigated Animal Hoarding Disorder. In addition, it aimed to verify the sociodemographic characteristics about individuals with this disorder, conditions of the environment and the animals, quantity and species of hoarded animals, the diagnostic criteria and the therapeutic interventions applied. Empirical or documental articles written in English, Spanish or Portuguese were analyzed, with no use of time restrictors. Among 75 articles found 9 were analyzed. It was observed that hoarders were females and approximately hoarded more than 30 animals. The environments were found under unhealthy conditions and cats and dogs were the most hoarded animals. This disorder produces great suffering for the individual, their families and also their animals. It is concluded that due to the lack of empirical studies on the subject, researches need to be made in order to fill this gap and, consequently, to construct intervention strategies.
\end{abstract}

Keywords: Animal Hoarding Disorder; Diagnostic criteria; Characteristics of animal hoarders.

\section{Transtorno de acumulação de animais: uma revisão sistemática}

\section{Resumo}

O objetivo principal deste artigo foi identificar estudos que investigaram o transtorno de acumulação de animais. Além disso, buscou verificar as características sociodemográficas dos indivíduos com esse transtorno, as condições do ambiente e dos animais, quantidade e espécies de animais acumulados, critérios diagnósticos e as intervenções terapêuticas utilizadas. Analisou-se artigos empíricos ou documentais, redigidos na língua inglesa, espanhola ou portuguesa, sem restritor de tempo. Dentre os 75 artigos encontrados, analisou-se nove artigos. Observou-se que os acumuladores, são do sexo feminino e acumulam em média, mais de 30 animais. As condições das habitações eram insalubres, e os animais mais acumulados são cães e gatos. O transtorno produz grande sofrimento para o indivíduo, para sua família e também para os animais. Conclui-se que devido à carência estudos empíricos sobre a temática, pesquisas necessitam ser realizadas para sanar essa lacuna e, consequentemente, construir estratégias de intervenções.

Palavras-chave: Transtorno de Acumulação de Animais; Critérios diagnósticos; Características de acumuladores de animais.

\section{Trastorno de acumulación de animales: una revisión sistemática}

\section{Resumen}

El objetivo principal de este artículo fue identificar estudios que investigaran el trastorno de acumulación de animales. Además, se buscó verificar características sociodemográficas de los individuos con este trastorno, las condiciones del ambiente e de los animales, cantidad y especies de animales acumulados, los criterios diagnósticos y las intervenciones terapéuticas utilizadas. Se analizaron artículos empíricos o documentales, escritos en lengua inglesa, española o portuguesa, sin restricción de tiempo. De los 75 artículos encontrados, nueve fueron analizados. Se observó que los acumuladores, normalmente, eran de sexo femenino y acumulaban en media más de 30 animales. Las condiciones de las viviendas eran insalubres y los animales más acumulados eran canes y gatos. El trastorno produce gran sufrimiento para el individuo, su familia y también para los animales. Se concluye que debido a la falta de estudios empíricos sobre el tema, necesitan ser realizadas investigaciones para llenar este vacío y, consecuentemente, construir estrategias de intervención.

Palabras clave: Trastorno de Acumulación de Animales; Criterios diagnósticos; Características de acumuladores de animales. 
Animal Hoarding Disorder was described for the first time in the scientific community by Worth and Beck (1981), under the nomenclature of "owners of many animals". The researchers investigated 31 individuals who owned many animals in New York. Results demonstrated that these individuals owned, approximately, 34 cats and 23 dogs per house. Most of them were from low socioeconomic class and lived by themselves. Both individuals and animals were found in unhealthy conditions. The hoarding was a result from incessant animal collection and the unstoppable reproduction, besides the inability of the individual donate animals.

Until the late 1990s, animal hoarding was not a phenomenon studied and poorly described in scientific literature. Patronek (1999) was the first researcher to propose diagnostic criteria to identify animal hoarders and to present this condition as a Public Health issue. Hoarding Disorder is considered a complex phenomenon that causes public health problems. It produces direct impact on the health of hoarders and their families that live in contact with unhealthy conditions and with high risk of zoonoses. The problem extends to the environment and nearby neighbors, who are also exposed to these risk factors and others such as noise and bad smell. It is also possible to emphasize that animals are affected by the state of hoarding, presenting precarious conditions of health and malnutrition, and confined in inadequate spaces (Bratiotis, Schmalisch, $\&$ Steketee, 2011). Thus, there is a potential damage to the health of the hoarder, the neighbors, and also the animals (Svanberg \& Arluke, 2016).

Nowadays, Animal Hoarding Disorder is described as a special manifestation of hoarding disorder (American Psychiatric Association, 2014). However, previously neither the fourth edition of the Diagnostic and Statistical Manual of Mental Disorders DSMIV-TR (American Psychiatric Association, 2002) nor the last Brazilian edition of International Statistical Classification of Diseases ICD-10 of World Health Organization (1993) presented descriptions of hoarding disorder. In DSM-IV-TR (American Psychiatric Association, 2002), hoarding was only described as a symptom of Obsessive-Compulsive Personality Disorder and Obsessive-Compulsive Disorder.

Hoarding disorder is only contemplated as a separate nosological category in the 5th Edition of Diagnostic and Statistical Manual of Mental Disorders (2014) that presents Animal Hoarding Disorder as a special manifestation in a brief description of seven lines. Basically for DSM-5, the criteria are hoarding many animals and failure to provide minimum patterns of nutrition, sanitation and veterinary care. Therefore, animal hoarding is understood as a special manifestation of hoarding disorder. The unhealthy conditions are more expressive and the insight capacity is poorer in animal hoarders, where may occur simultaneous hoarding of inanimate objects (American Psychiatric Association, 2014).

According to Williams (2014) more than the number of animals hoarded, what defines the disorder is the inability of the individual to offer minimum necessary care to animals. These animals are found living in precarious conditions. Besides, the individual fails to recognize the suffering of animals, the lack of sanitation in the domicile and uncontrolled hoarding. The situation found, most part of the time, is confinement in small and inadequate spaces due to the excessive quantity of domestic animals, especially cats and dogs. However, birds and farm animals can also be hoarded. These animals are often hungry, caged, stacked and even dead. Hoarders insist and continue hoarding animals, even with the progressive deterioration of the environment.

Hoarding disorder brings several consequences to hoarders, such as difficulties in walking around the house, cooking, cleaning, personal hygiene and even sleeping. Their quality of life is considerably impaired. In severe cases, hoarding may put the individuals in fire risk, fall risk (especially elderly), as well as submitting to deficient sanitary conditions and other health risks. This disorder is associated with professional impairment, poor physical health and intense utilization of social services. Family relationships often become complicated. The conflict with neighbors and local authorities is common, and a substantial proportion of individuals with hoarding disorder have been or are involved in legal proceedings (American Psychiatric Association, 2014).

Data on the prevalence of hoarding disorder in the Brazilian context are still not available. In international scenery, United States and Europe estimate that the disorder is present in approximately 2 to $6 \%$ of the population (American Psychiatric Association, 2014).

The Animal Hoarding Disorder brings multiple losses to hoarders and produces negative impact to their families, close neighbors and also to animals. It consists of a new field of scientific study, unknown and intriguing because involves psychopathological aspects of human-animal relationship. However, the criteria for its identification and classification are not wellestablished yet, and it is necessary to improve the criteria that characterize the disorder (Mataix-Cols, 2014).

In this perspective, the present study aims, through a systematic review of the literature, to identify studies that investigated Animal Hoarding Disorder. In 
addition, it attempted to verify the sociodemographic characteristics of individuals with Animal Hoarding Disorder, environmental and animal conditions, quantity and species of hoarded animals, diagnostic criteria and therapeutic interventions used.

\section{Method}

The present study followed the recommendations of PRISMA Declaration that aims to guide the preparation of systematic reviews of the literature and metaanalyses in the health field (Moher, Liberati, Tetzlaff, \& Altman, 2009). Searches were made in Cochrane Data base of Systematic Review (CDSR), Database of Abstracts of Reviews of Effects (DARE) in order to verify the existence of previous systematic reviews on the subject. In these searches, no studies were specifically found on the subject. With the descriptors used, the search was not able to find any systematic review about the subject. This aspect highlights the necessity for studies that contemplate the current scenario of scientific publications on the theme and the gaps that need to be addressed.

There is not a descriptor in Portuguese for Animal Hoarder or Animal Hoarding Disorder in the tool Descriptors of Health Sciences (DeHS). Therefore, in the process of construction of the string, the TermFinder tools were used for the PsychINFO base, in the Medical SubjectHeadings (MeSH) index of the Pubmed/Medline database. The descriptors "Animal Hoarding" OR "Animal Hoarding Behavior" were chosen. In order to contemplate the largest number of studies, the Boolean operator "OR" was used.

In the search process in the databases, the descriptors to retrieve the articles could be present in any part of the article. In the process of search, quotation marks were used in each descriptor. The search in the databases was made by two researchers and were only included in this review articles that meet the criteria of inclusion. This procedure was made on May $10^{\text {th }}, 2016$.

The criteria of inclusion were: (1) Articles in English, Spanish or Portuguese; (2) Empirical articles involving individuals with Animal Hoarding Disorder; (3) Documental articles that investigate detailed report of animal hoarders. These criteria were applied through the reading of the title and abstract of articles. The criteria of exclusion were: (1) News on the subject; and (2) Articles that did not address objects hoarding and animal hoarding. No restrictor regarding the year of the publication of the articles was applied, including all studies that contemplate the previously described criteria.

Independently, the researchers analyzed the relevant articles and delivered opinions on their inclusion or exclusion in the review. In cases of divergences of opinion, a third researcher was contacted. After the process of selecting the studies and defining, those that would be included in the review, the researchers tabulated the data. A fluxogram (Figure 1) of the choice of articles is presented.

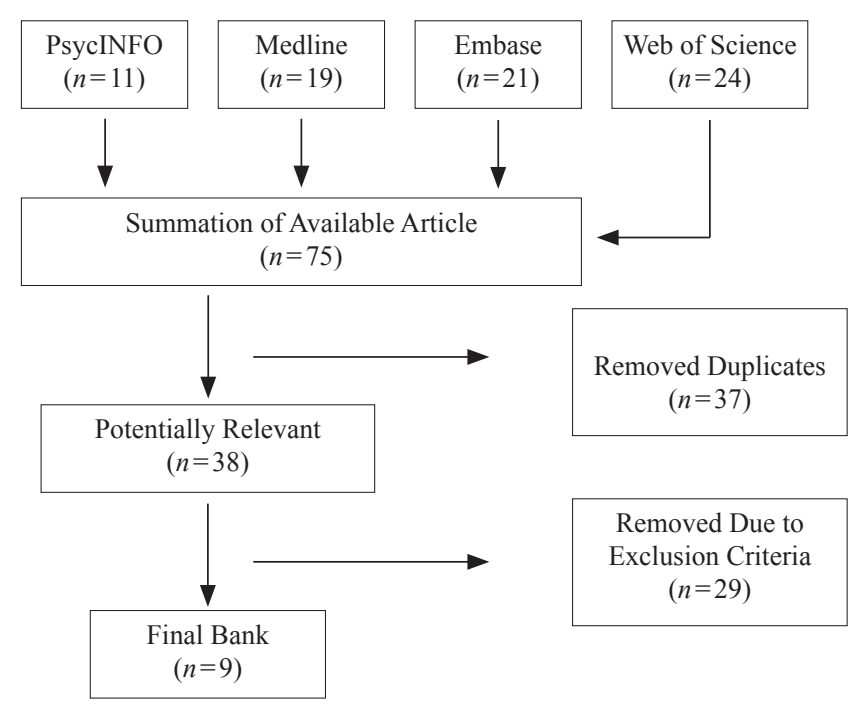

Figure 1. The fluxogram demonstrates the analysis of inclusion and exclusion of the systematic review studies.

\section{Results}

In order to present information on articles included in this systematic review, Table 1 is presented. It brings synthetically the authorship of articles, objectives, sample characteristics, types of hoarded animals and the main findings.

Among the nine articles that compose the review, only two discussed the empirical studies directly made with individuals affected by Animal Hoarding Disorder (Cantillo \& Nieto, 2015; Steketee et al., 2011). The other six studies were documental type that had no direct contact with the hoarders, only analyzed case reports from governmental and non-governmental institutions.

The nine articles analyzed included 238 participants, $180(90 \%)$ women and $58(10 \%)$ men, between the ages of 18 to 98 years. The studies were published from 1999 to 2016. It was observed that there were more women than men involved in research, and two studies were composed only of female participants (Cantillo \& Nieto, 2015; Svanberg, Ingvar, Arluke, \& Arnold 2016). Both participants of empirical studies and the case reports were recruited in animal welfare institutes, governmental and non-governmental. 
TABLE 1

Data extraction from articles

\begin{tabular}{|c|c|c|c|c|}
\hline $\begin{array}{l}\text { Reference and } \\
\text { Country }\end{array}$ & Research Question & $\begin{array}{l}\text { Design, participants and } \\
\text { documents }\end{array}$ & $\begin{array}{l}\text { Types and number of } \\
\text { animals }\end{array}$ & Main Findings \\
\hline $\begin{array}{l}\text { Patronek (1999) - } \\
\text { United Estates of } \\
\text { America }\end{array}$ & $\begin{array}{l}\text { Characterize the } \\
\text { Animal Hoarding }\end{array}$ & $\begin{array}{l}\text { Documental, } 54 \text { case } \\
\text { reports } \\
\text { Women }=41 \\
\text { Men }=13 \\
\text { Average age }=60 \text { years old }\end{array}$ & $\begin{array}{l}\text { Dogs, cats, farm } \\
\text { animals and birds } \\
\text { Average }=39\end{array}$ & $\begin{array}{l}\text { In } 43 \text { cases there was report of dead or ill } \\
\text { animals, and the individual was not able to } \\
\text { recognize the existence of problems with animals } \\
\text { in more than half of these cases. About } 50 \% \text { of } \\
\text { the hoarders lived by themselves. At least one } \\
\text { quarter of hoarders was later institutionalized or } \\
\text { went to reside under tutorship or supervised. }\end{array}$ \\
\hline $\begin{array}{l}\text { HARC (2002) - } \\
\text { Canada }\end{array}$ & $\begin{array}{l}\text { Investigate the } \\
\text { commitment of daily } \\
\text { activities and sanitary } \\
\text { conditions of Animal } \\
\text { Hoarders' residences }\end{array}$ & $\begin{array}{l}\text { Documental, } 71 \\
\text { professionals reports about } \\
\text { cases } \\
\text { Women }=59 \\
\text { Men }=12 \\
\text { Average age }=54 \text { years old }\end{array}$ & $\begin{array}{l}\text { Cats, dogs, birds, } \\
\text { reptiles, small mammals } \\
\text { and farm animals } \\
\text { Average }=84\end{array}$ & $\begin{array}{l}\text { Daily activities were compromised in most of } \\
\text { the cases. All cases presented object hoarding. } \\
\text { Hoarders between the ages of } 50 \text { and } 64 \text { years } \\
\text { old tend to hoard more animals when compared } \\
\text { to individuals less than } 50 \text { years old. }\end{array}$ \\
\hline $\begin{array}{l}\text { Reinisch (2009) - } \\
\text { Canada }\end{array}$ & $\begin{array}{l}\text { Characterize cases of } \\
\text { Animal Hoarders }\end{array}$ & $\begin{array}{l}\text { Documental, } 6 \text { case reports } \\
\text { Women }=05 \\
\text { Men }=01 \\
\text { Average age }=50 \text { years old }\end{array}$ & $\begin{array}{l}\text { Cats, dogs, rabbits and } \\
\text { horses } \\
\text { Average }=53\end{array}$ & $\begin{array}{l}\text { Women are more susceptible to Animal } \\
\text { Hoarding and, generally, elderly individuals } \\
\text { are more prone. In all cases veterinarians were } \\
\text { concerned on health and state of the animals } \\
\text { that were improper. In four of these cases, the } \\
\text { animals were in dreadful health conditions that } \\
\text { led the veterinarians to proceed with euthanasia. }\end{array}$ \\
\hline $\begin{array}{l}\text { Calvo, Duarte, } \\
\text { Bowen, } \\
\text { Bulbena,\&Fatjó } \\
\text { (2014) - Spain }\end{array}$ & $\begin{array}{l}\text { Obtain data on Animal } \\
\text { Hoarding }\end{array}$ & $\begin{array}{l}\text { Documental, } 27 \text { reports } \\
\text { Women }=14 \\
\text { Men }=13 \\
\text { Average age }=65 \text { years old }\end{array}$ & $\begin{array}{l}\text { Dogs, cats and farm } \\
\text { animals } \\
\text { Average }=50\end{array}$ & $\begin{array}{l}\text { Among the cases, } 44 \% \text { hoarded other objects. } \\
\text { Only one case (woman) has recognized that } \\
\text { animals welfare were injured. The large number } \\
\text { of injured animals is explained by abandoned } \\
\text { animals collection }(69 \%) \text { and uncontrolled } \\
\text { reproduction }(78 \%) \text {. }\end{array}$ \\
\hline $\begin{array}{l}\text { Steketee et al., } \\
\text { (2011) - United } \\
\text { Statesof America }\end{array}$ & $\begin{array}{l}\text { Investigate the } \\
\text { characteristics and } \\
\text { background that } \\
\text { may explain Animal } \\
\text { Hoarding }\end{array}$ & $\begin{array}{l}\text { Transversal, } \\
27 \text { individuals. } \\
\text { Women }=25 \\
\text { Men }=2 \\
\text { Average age }=47 \text { not } \\
\text { informed }\end{array}$ & $\begin{array}{l}\text { Cats, dogs, horses, } \\
\text { sheep, goats, reptiles, } \\
\text { birds, rabbits, rodents } \\
\text { and wildlife } \\
\text { Average }=31\end{array}$ & $\begin{array}{l}\text { Explanatory model for hoarding: } \\
\text { 1) inability to develop attachment early in life; } \\
\text { 2) higher frequency of stressful events in } \\
\text { childhood; } \\
\text { 3) negative affection in childhood; } \\
\text { 4) deficit function in decision-making skills and } \\
\text { organizational skills; } \\
\text { 5) dependence on animals to provide emotional } \\
\text { comfort. }\end{array}$ \\
\hline $\begin{array}{l}\text { Joffe, Shannessy, } \\
\text { Dhand,Westman, } \\
\text { \& Fawcett (2014) - } \\
\text { Australia }\end{array}$ & $\begin{array}{l}\text { Investigate the } \\
\text { characteristics of } \\
\text { Animal Hoarding in } \\
\text { Australia and compare } \\
\text { with other studies }\end{array}$ & $\begin{array}{l}\text { Documental, } 29 \text { reports. } \\
\text { Women }=21 \\
\text { Men }=8 \\
\text { Average age }=54,8 \text { years } \\
\text { old }\end{array}$ & $\begin{array}{l}\text { Dogs, cats, horses, birds } \\
\text { and farm animals. } \\
\text { Average }=41 .\end{array}$ & $\begin{array}{l}\text { Dog was the most hoarded animal. Dead animals } \\
\text { were found in } 41 \% \text { of cases. } \\
\text { Similarities were found in Animal Hoarding in } \\
\text { Australia and in other countries. Most cases also } \\
\text { hoarded objects. }\end{array}$ \\
\hline $\begin{array}{l}\text { Ockenden, Groef, } \\
\text { \&Marston (2014) - } \\
\text { Australia }\end{array}$ & $\begin{array}{l}\text { Identify the } \\
\text { characteristics of } \\
\text { Animal Hoarding }\end{array}$ & $\begin{array}{l}\text { Documental, } 22 \text { reports } \\
\text { Women }=13 \\
\text { Men }=9 \\
\text { Average age }=55 \text { years old }\end{array}$ & $\begin{array}{l}\text { Dogs, cats, rabbits, } \\
\text { wildlife and farm } \\
\text { animals } \\
\text { Does not present } \\
\text { average, but cases with } \\
10 \text { to } 180 \text { animals }\end{array}$ & $\begin{array}{l}\text { The most common animal hoarded was cat. } \\
\text { The most common source of animals was } \\
\text { uncontrolled reproduction and } 45 \% \text { hoarded } \\
\text { objects. Most stories from hoarders involved } \\
\text { some traumatic event in their life. }\end{array}$ \\
\hline $\begin{array}{l}\text { Cantillo\&Nieto } \\
\text { (2015) - Colombia }\end{array}$ & $\begin{array}{l}\text { Report Animal } \\
\text { Hoarding case of an } \\
\text { elderly individual }\end{array}$ & $\begin{array}{l}\text { Transversal involving } 1 \\
\text { case } \\
\text { Women }=1 \\
\text { Age }=83 \text { years old }\end{array}$ & $\begin{array}{l}\text { Dogs and cats } \\
\text { Average }=21\end{array}$ & $\begin{array}{l}\text { The neuropsychological evaluation demonstrated } \\
\text { a moderate cognitive impairment affecting the } \\
\text { higher functions, especially frontal-subcortical } \\
\text { organization. Attention deficit was observed, } \\
\text { presenting deficits in verbal and visual learning, } \\
\text { failing in encode and recall the information in an } \\
\text { organized manner. }\end{array}$ \\
\hline $\begin{array}{l}\text { Svanberg, Ingvar, } \\
\text { Arluke, \& Arnold } \\
\text { (2016) - Sweden }\end{array}$ & $\begin{array}{l}\text { Describe a case of } \\
\text { Animal Hoarding }\end{array}$ & $\begin{array}{l}\text { Documental, reports and } \\
\text { interviews of } 1 \text { case } \\
\text { Women }=1 \\
\text { Age }=68 \text { years old }\end{array}$ & $\begin{array}{l}\text { Swan } \\
\text { Maximum = } 11\end{array}$ & $\begin{array}{l}\text { The lady lived alone with animals in a } 25 \mathrm{~m}^{2} \\
\text { apartment very dirty. The apartment had } 150 \\
\text { animals. The woman was tried, the court } \\
\text { considered negligent and she had submitted } \\
\text { the birds suffering, confining the animals in the } \\
\text { apartment in unsatisfactory conditions. } \\
\text { There were not made psychological assessments. }\end{array}$ \\
\hline
\end{tabular}


Concerning the average number of animals hoarded per case, only one article does not indicate this datum (Ockenden, Groef, \& Marston, 2014). The other eight articles presented the average number of animals, ranging from 11 (Svanberg et al., 2016) to 84 per household (HARC, 2002). Considering the types of hoarded animals, it was observed that hoarding of dogs and cats were more frequent in eight of the nine articles, the only exception was a study in Sweden where swans were hoarded (Svanberg et al., 2016).

In relation to the objects hoarding associated to animal hoarding, it was verified that three articles indicated that all individuals of their sample, besides animal hoarding, also hoarded inanimate objects (Cantillo \& Nieto, 2015; HARC, 2002; Svanberg et al., 2016). Two articles did not present information on the simultaneous existence of animals and objects in simultaneous hoarding (Patronek, 1999; Shannessy, Westman \& Fawcett, 2014). The other four studies demonstrate that approximately half of the sample did not hoarded objects (Ockenden et al, 2014; Steketee et al, 2011).

Only two studies presented information regarding the difference in the number of animal hoarded by women and men, in both cases women had a higher average number of animals compared to men (HARC, 2002; Reinisch, 2009). Concerning the age group of the animal hoarders, in eight articles approximately $30 \%$ of the sample presented individuals over 60 years old, only one study did not inform the age of the participants (Steketee et al., 2011). Regarding the sanitation conditions, all the articles emphasized that hoarders lived in unhealthy conditions.

No data on the therapeutic interventions used with the hoarders were found in the articles included in the review. In four articles the animals were removed, but due to the lack of therapeutic monitoring, returning back to the residences of hoarders it was verified that the hoarders were with a large number of animals again (Cantillo \& Nieto, 2015; HARC., 2002; Ockenden et al, 2014; Reinisch, 2009; Svanberg et al, 2016).

None of the articles used DSM-5 criteria for identifying the individual with Animal Hoarding Disorder. Five articles (Cantillo \& Nieto, 2015; HARC, 2002; Patronek, 1999; Reinisch, 2009; Svanberg et al, 2016) used the following definition: 1) A large number of animals; 2) Precarity in nutrition, poor sanitation and veterinary care; 3) Do not act on the state of deterioration of animals and the environment or on the negative effect of hoarders on the health and well-being of other family members. 4) The individuals have an inability to perceive the negative consequences of hoarding.

\section{Discussion}

This article aimed to identify studies that investigated Animal Hoarding Disorder. Furthermore, this systematic review aimed to investigate the sociodemographic characteristics, the condition of environment and the condition of animals, the diagnostic criteria and the interventions used. Due to the lack of empirical studies on the subject, it was decided to include documentary studies in this systematic review.

The animal hoarders are mostly women and elderly individuals who usually live alone. Based on the articles included in the review, it was possible to conclude that there is a positive association between the occurrence of Animal Hoarding Disorder and the increasing age (Ockenden, Groef \& Marston, 2014).

The most frequently hoarded species of animals were dogs and cats. This finding may be related to the process of domestication of species by humans since dogs and cats are highlighted among domestic species, used as companion (Fuck, Fuck, Delarissa \& Curt, 2006). The population of dogs and cats are increasing in Brazil and in the world. The easy access to these animals may be the main reason they are the most hoarded animals.

Some studies have tried to differentiate animal hoarding from individuals who have many animals, but are not considered hoarders. For Steketee et al., (2011) to have a large number of animals (for example 20 or more) with proper treatment and lack of interference in home or in functioning of individual personal, are characteristics to differentiate hoarders from people with many animals.

Considering that all studies report sick or dead animals, it is possible to notice that the information agrees with the diagnostic criteria of DSM-5. This behavior, characterized as a loss in perceptual ability or lack of empathy, may be associated with poor insight that is present in the disorder, even presenting difficulties to remove animals after death (American Psychiatric Association, 2014; Pertusa et al, 2010; Lima, 2011). Often the situation is confinement in small spaces, insufficient for such large numbers of animals, and the individual continues hoarding animals even with the progressive deterioration of the environment (Williams, 2014).

The Hoarding Disorder presents itself as a special manifestation of Hoarding Disorder, because environmental conditions are unhealthier and the insight of hoarders is generally poorer (American Psychiatric Association, 2014). More than the number of animals, what defines the disorder is the inability 
of the individual to provide minimal necessary care to the animals, providing precarious living conditions. In addition, there are differences between hoarding objects and "hoarding" animals. Inanimate objects do not require attention, while animals require constant care, even if the hoarders are only able to provide the minimum (Nathanson, 2009; Reinisch, 2008).

Animal Hoarding Disorder can be characterized as a serious public health problem since it has consequences for hoarders, family, animals and community. In addition, it generates economic consequences for the city when the animals need to be removed from the hoarders. While in the objects hoarding the items can simply be discarded, in animal hoarding the fate of the animals becomes an economic problem for the city, which becomes responsible for their care and maintenance. In the articles of this review it was verified that when the process was remove the animals, they were referred for adoption or were euthanized (Cantillo \& Nieto, 2015; HARC., 2002; Ockenden et al, 2014; Reinisch, 2009; Svanberg et al, 2016), probably not to generate costs for the city.

Based on the results, some common factors in animal hoarding were perceived, such as psychological and behavioral characteristics of individuals with hoarding disorder, as poor insight capacity, difficulties in donating animals and deficits organization. Some studies report that beliefs about responsibility, the need to control and excessive emotional connection with animals are also common in these individuals (Steketee et al., 2011). It is noted that certain factors aggravate the hoarding, as abandonment of animals by neighbors and also uncontrolled reproduction (HARC, 2002; Patronek, 1999).

Organizing the data collected in the review is possible to think in an explanatory model for hoarders. Some aspects would be probable predictors, as the inability to develop affection early in life, with higher frequency of stressful events in childhood, negative affection in childhood, deficient in decision-making and organizational skills (HARC, 2002; Patronek 1999; Steketee et al, 2011). It is observed in some cases the dependency of animals to provide emotional comfort for the individual (Steketee et al., 2011). These findings confirm the hypothesis by Cantillo and Nieto (2015), that animal hoarders have impairment in the frontal cortex. However, this hypothesis lacks of further studies.

Other studies indicate that Animal Hoarding Disorder is positively associated with dementia processes, most often observed in elderly population (HARC, 2002; Patronek, 1999; Beck \& Worth, 1981). Disorder of substance use, lack of impulse control and privation of care in childhood are considered other aspects related (Ramos Cruz, Ellis \& Reche-Junior, 2013).

Studies suggest that hoarders may have comorbid psychotic symptoms, such as delusional thoughts. These individuals believe that they have a special ability to understand and sympathize with their animals. Despite all evidences contradicting their perception, most hoarders believe and claim that their animals are being well cared (Calvo et al. 2014; Frost, 2000; Patronek, 1999).

High rates of psychopathology comorbid to hoarding disorder are found in clinical populations (Frost, Steketee, \& Tolin, 2011). DSM-5 reports that about $75 \%$ of individuals with hoarding disorder have mood disorders or anxiety disorders. More frequent comorbid psychopathologies are mentioned as major depressive disorder (up to $50 \%$ of cases) and social and generalized anxiety disorders. Obsessive-compulsive disorder is also referred as possible comorbidity and affects about $20 \%$ of individuals (American Psychiatric Association, 2014). It is also mentioned in the scientific literature, but in a less proportion, the panic disorder, posttraumatic stress disorder, and eating disorder (Pertusa, et al, 2008).

The findings of this article present limitations. It was not possible to perform a proper evaluation of the scientific quality of the studies included in the review since these articles present a heterogeneous and small samples methodology. The articles found are exploratory, where the main objectives were to investigate the characteristics of individuals with Animal Hoarding Disorder. The data presented by the studies point to the need for a differentiated attention in the treatment of these individuals. However, none of the studies performed therapeutic interventions, reinforcing the conclusion that there is a lack of research in the area and the necessity for research that may contribute to this problem.

Finally, it can be concluded that Animal Hoarding Disorder produces significant suffering for the hoarder, for the family and neighborhood, especially for the animals that live in precarious conditions of space, sanitation, feeding and veterinary care. This mental disorder should be dealt as a public health problem, due to the high cost for the hoarder and also for governmental and non-governmental institutions. Therefore, this study emphasizes the need for development of empirical studies with this population still neglected and poorly studied. It is important to understand this disorder and to develop therapeutic strategies able to help in solving this problem. 


\section{Referências}

*Calvo, P., Duarte, C., Bowen, J., Bulbena, A., \& Fatjó, J. (2014). Characteristics of 24 cases of animal hoarding in Spain. Animal Welfare, 23(2), 199-208. http://dx.doi.org/10.7120/09627286.23.2.199

*Hoarding of Animals Research Consortium (HARC). (2002). Health implications of animal hoarding. Health \& Social Work, 27(2), 125-136. http://dx.doi.org/10.1093/hsw/27.2.125

*Joffe, M., O'Shannessy, D., Dhand, N. K., Westman, M., \& Fawcett, A. (2014). Characteristics of persons convicted for offences relating to animal hoarding in New South Wales. Australian veterinary journal, 92(10), 369-375. http:// dx.doi.org/10.1111/avj.12249

*Ockenden, E. M., De Groef, B., \& Marston, L. (2014). Animal Hoarding in Victoria, Australia: An Exploratory Study. Anthrozoös, 27(1), 33-47. http://dx.doi.org/10.2752/175303714X13837396326332

*Patronek, G. J. (1999). Hoarding of animals: an under-recognized public health problem in a difficult-to-study population. Public Health Reports, 114(1), 81. http://dx.doi.org/10.1093/phr/114.1.81

*Reinisch, A. I. (2009). Characteristics of six recent animal hoarding cases in Manitoba. The Canadian Veterinary Journal, $50(10), 1069$.

*Saldarriaga-Cantillo, A. \& Rivas Nieto, J. C. (2015). Noah Syndrome: A Variant of Diogenes Syndrome Accompanied by Animal Hoarding Practices. Journal of elder abuse \& neglect, 27(3), 270-275. http://dx.doi.org/10.1080/089465 66.2014 .978518

*Slyne, K. E., Tolin, D. F., Steketee, G., \& Frost, R. O. (2013). Characteristics of animal owners among individuals with object hoarding. Journal of Obsessive-Compulsive and Related Disorders, 2(4), 466-471. http://dx.doi.org/10.1016/j. jocrd.2012.11.003

*Steketee, G., Gibson, A., Frost, R. O., Alabiso, J., Arluke, A., \& Patronek, G. (2011). Characteristics and antecedents of people who hoard animals: An exploratory comparative interview study. Review of General Psychology, $15(2), 114$. http://dx.doi.org/10.1037/a0023484

*Svanberg, I. \& Arluke, A. (2016). The Swedish Swan Lady. Society \& animals, 24(1), 63-77. http://dx.doi. org/10.1163/15685306-12341388

American Psychiatric Association (2014). Manual Diagnóstico e Estatístico de Transtornos Mentais (DSM-5). Porto Alegre: Artmed.

American Psychiatric Association. (2002). Diagnostical and Statistical Manual of Mental Disorders (DSM-IV) (4th ed.). Washington, DC: Author.

Fuck, E. J., Fuck, E. T., Delarissa, F., \& Curt, C. E. (2006). Relação Homem X Animal Aspectos psicológicos e comportamentais. Revista Nosso Clínico, 9(49).

Lima, R. (2011). Acumuladores compulsivos: uma nova patologia psíquica. Revista Espaço Acadêmico, 11(126), 208-215.

Mataix-Cols, D. (2014). Hoarding disorder. New England Journal of Medicine, 370(21), 2023-2030. http://dx.doi. org/10.1056/NEJMcp1313051

Moher, D., Liberati, A., Tetzlaff, J., \& Altman, D. G. (2009). Preferred reporting items for systematic reviews and metaanalyses: the PRISMA statement. Annals of internal medicine, 151(4), 264-269. http://dx.doi.org/10.1371/journal. pmed 1000097

Pertusa, A., Frost, R. O., Fullana, M. A., Samuels, J., Steketee, G., Tolin, D. ..., \& Mataix-Cols, D. (2010). Refining the diagnostic boundaries of Compulsive Hoarding: a critical review. Clinical Psychology Review, 30(4), 371-86. Recuperado de: http://www.sciencedirect.com/science/article/pii/S0272735810000206 http://dx.doi.org/10.1016/j.cpr.2010.01.007

Ramos, D., Cruz, N. O., Ellis, S., Hernandez, J. A. E., \& Reche-Junior, A. (2013). Early stage animal hoarders: are these owners of large numbers of adequately cared for cats?. Human-Animal Interaction Bulletin, 1(1), 55-69.

Worth, D. and Beck, A. M. (1981). Multipleownershipofanimals in New York City. Transactions \& Studies of the College of Physicians of Philadelphia, 3(4): 280-300.

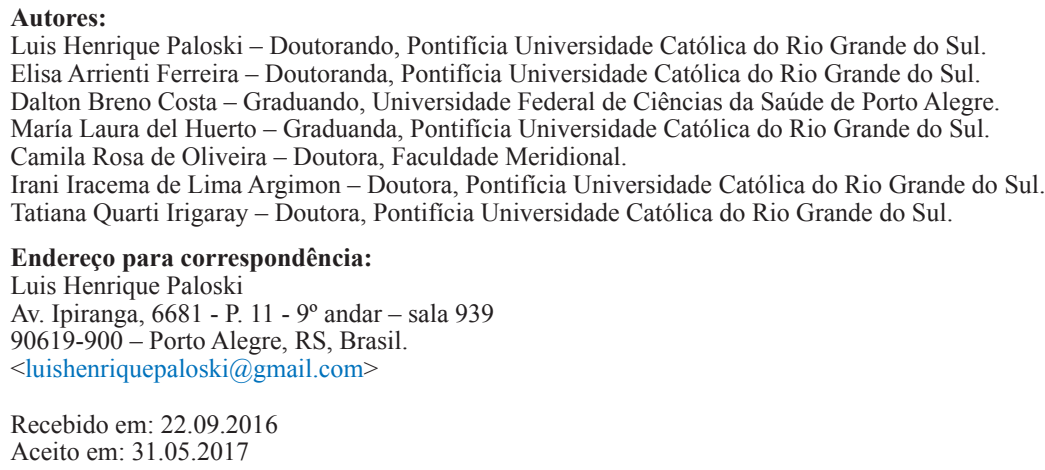

